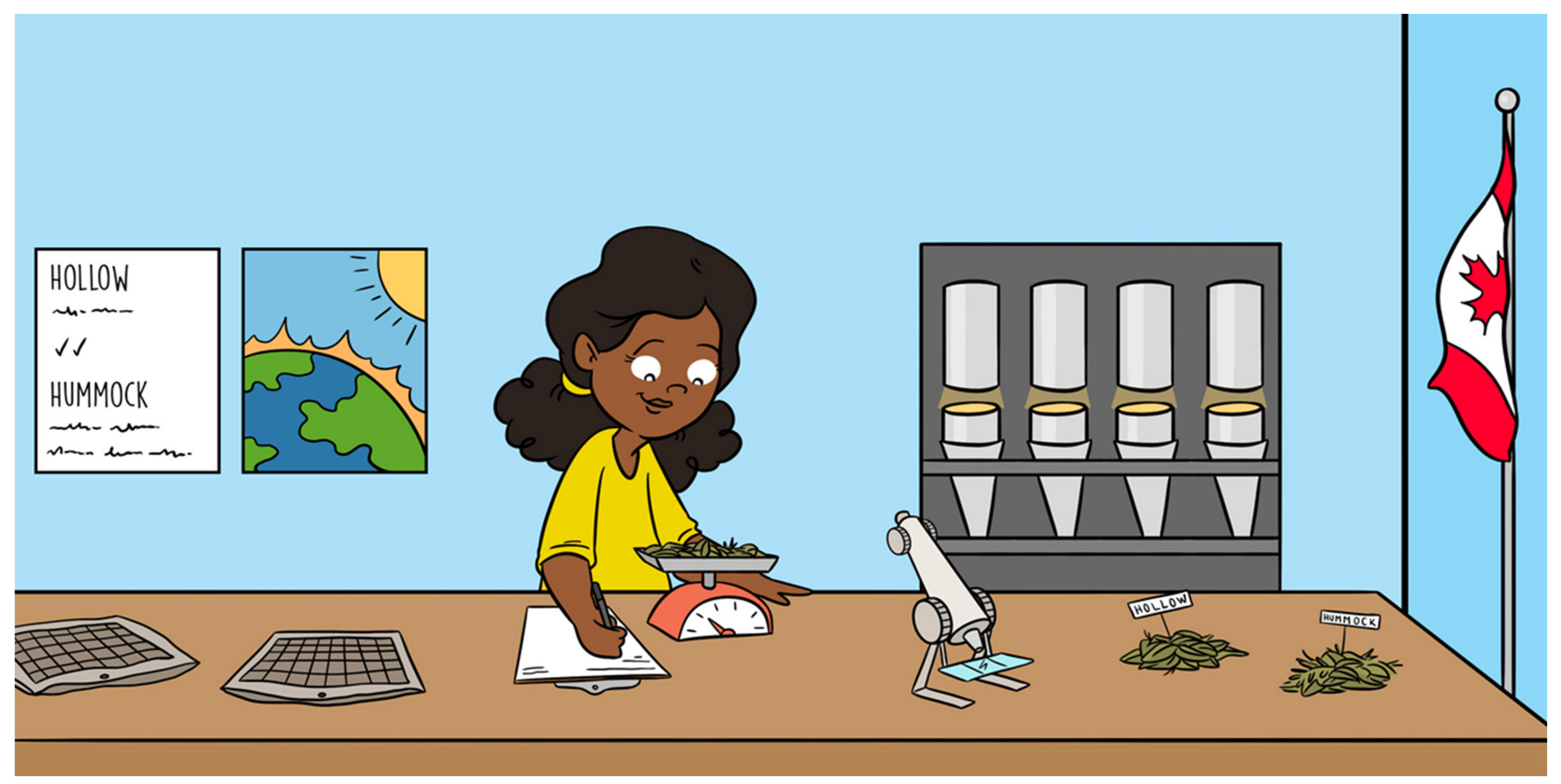

\title{
DECOMPOSITION IN PEATLANDS: WHO ARE THE PLAYERS AND WHAT AFFECTS THEM?
}

\section{Carlos Barreto ${ }^{* t}$ and Zoë Lindo ${ }^{+}$}

Soil Biodiversity and Ecosystem Function Laboratory, Department of Biology, Biotron Experimental Climate Change Research Centre, Western University, London, ON, Canada

YOUNG REVIEWERS:

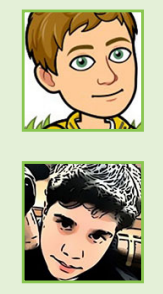

\section{ADAM}

AGE: 14

ALEXANDER

AGE: 12
All soils store carbon. As plants grow, they take up carbon from the atmosphere and this carbon enters the soil when they die. This dead plant material slowly decomposes as organisms, such as bacteria, fungi, and tiny animals called mites and springtails use this carbon as a food source. Decomposition is very slow in peatlands, and as a result, much of the carbon from dead plants remains in the soil, which can help slow climate warming. Decomposition in peatlands depends on how wet the soil is, and the different types of plants and soil organisms. We discovered that, in a peatland in northern Canada, dead plant material of different plant types decomposed at different rates, and more mites and springtails aiding in decomposition were found in wetter areas. Because peatlands are important for carbon storage, understanding who the players of decomposition are is important for understanding how to slow climate warming. 


\section{DECOMPOSITION}

Break-down of dead plants and animals which is measured as loss.

\section{ORGANISM}

An individual plant, animal, bacteria, or fungi.

\section{PEATLANDS}

Peatlands are a type of wetlands. The term "peatland" refers to the peat soil and the wetland habitat growing on its surface.

\section{Figure 1}

\section{Example of} simplified soil food web: Example of a predator (A) Predatory mite; Secondary decomposers. (B) Example of oribatid mites. (C) Example of springtail; Primary decomposers. (D) Fungi. (E) Fungi with bacteria at the bottom of the picture (ellipse). (F) Earthworms. (G) Vegetation in the peatland (only dead plants undergo decomposition). Arrows represent feeding links and point in the direction of the energy flow.

\section{INTRODUCTION}

Decomposition is the natural process of breaking down dead plants and animals. During decomposition, the chemical composition of dead plants and animals changes, and carbon is released into the atmosphere. Decomposition results from the activities of different types of organisms like fungi (Figure 1D), bacteria (Figure 1E), worms (Figure 1F), oribatid mites (Figure 1B), and springtails (Figure 1C). For example, bacteria and fungi directly breakdown dead plant material and are considered primary decomposers. Fungi and bacteria (primary decomposers) are eaten by oribatid mites and springtails (secondary decomposers). In turn, predatory mites (Figure 1A) consume secondary decomposers. Therefore, oribatid mites and springtails indirectly affect how fast decomposition happens.

Peatlands are important ecosystems that accumulate partially decomposed vegetation (Figure 1G), and thus store carbon contained in the decomposing plant material [1] (Figure 2A). Their main plant type is mosses (Figure 2E). Mosses are small, slow growing plants that need a lot of water to survive because they do not have real roots. They also decompose very slowly in peatlands after they die.

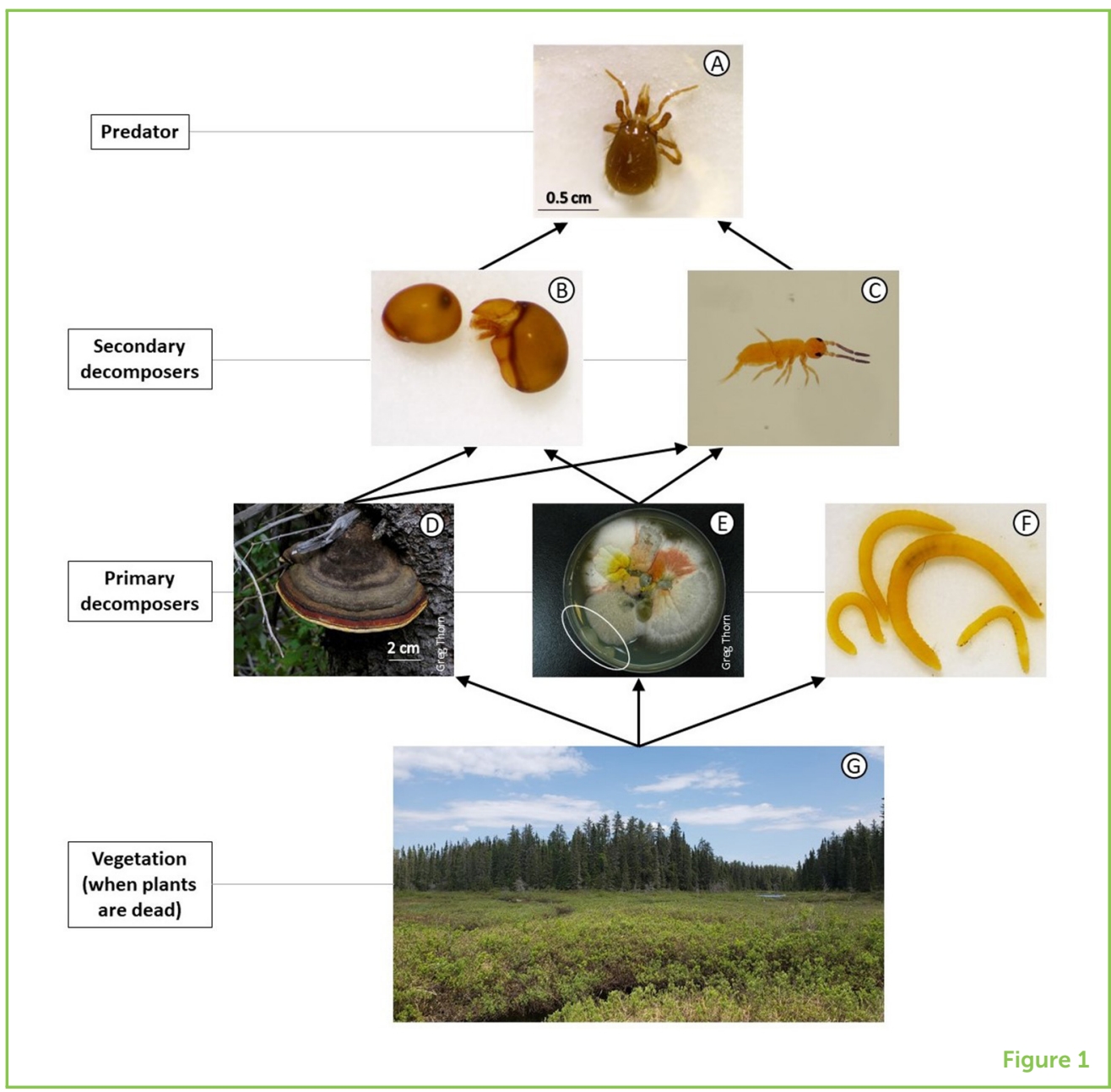


Figure 2

(A) Peatland. (B)

Hummock in front of a tree behind it. (C) Hollow with litterbags being deployed. (D) Litterbags $(10 \times 7 \mathrm{~cm}$ and the holes were $1 \mathrm{~mm}$ ). (E) Moss (species Sphagnum sp.). (F) Shrub (species Chamaedaphne calyculata). (G) Sedge (species Carex sp.). (H) Tullgren funnel (fauna extractor).

\section{CLIMATE CHANGE}

Climate change is the warming of the entire world, mostly caused by increasing levels of carbon dioxide in the atmosphere. The main source of carbon dioxide is

human activities.

\section{COMMUNITY}

A group of different species living in the same area and that interact with each other.

\section{SPECIES}

Organisms that share the same physical and genetic features; for example, all humans comprise a species, as do all dogs, all cats are considered a species too.
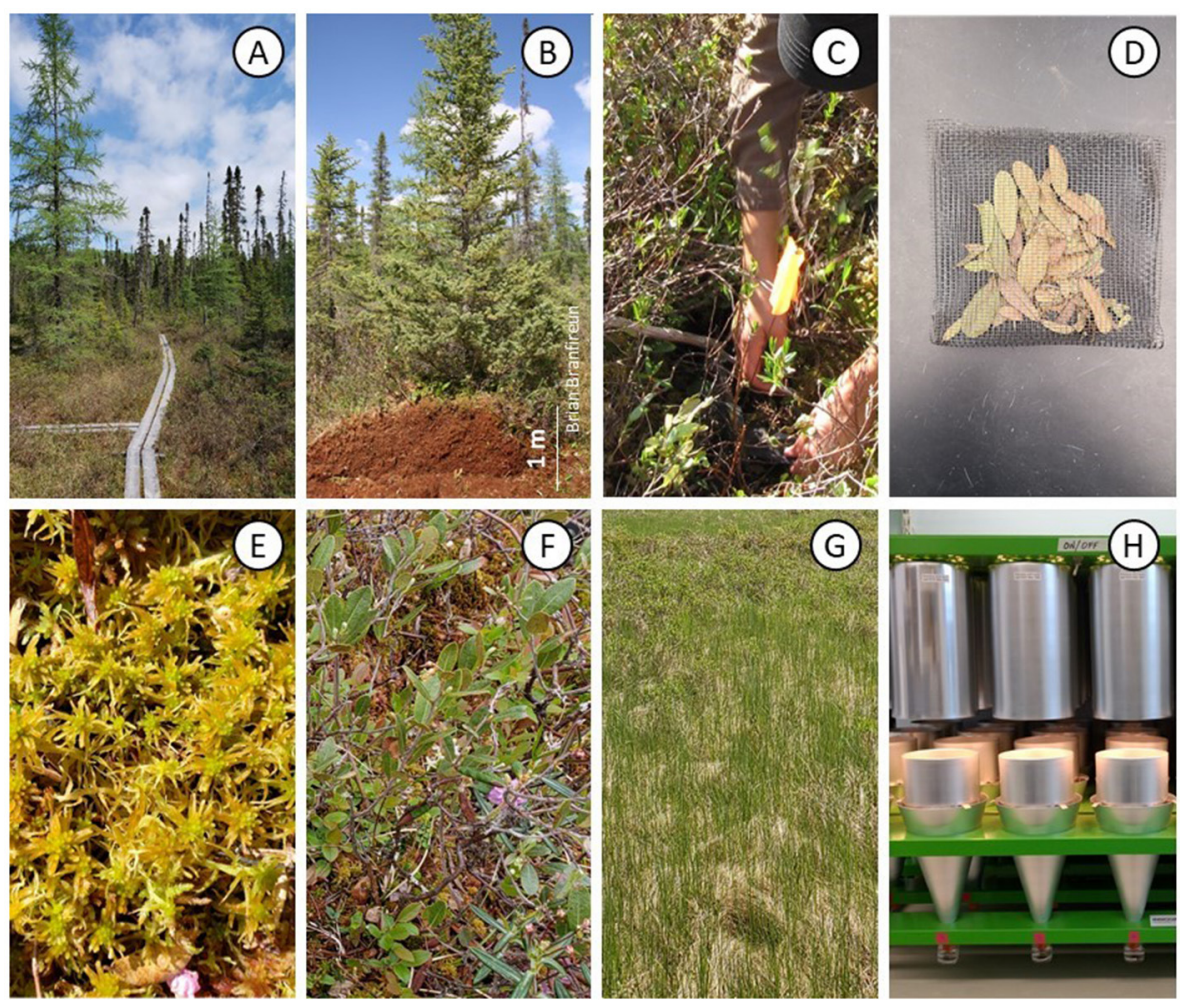

Figure 2

Peatlands are very wet, and decomposition is slow compared to other ecosystems like forests or grasslands which are drier. As a result, more dead plants accumulate, which means less carbon is released to the atmosphere from peatlands than from many other ecosystem types. In other words, more carbon enters and is held within peatland soils than is released back to the atmosphere as carbon dioxide. Carbon dioxide is a greenhouse gas that traps heat in the Earth's atmosphere, and therefore, peatlands can help slow or reverse climate warming. Peatlands could help reverse climate change by stocking more carbon in their soil.

Different factors can influence decomposition in peatlands; for instance, how wet the soil is, the different types of dead plant material present, and the soil community-the types of different organisms found in soil. Because we wanted to know what influences decomposition in peatlands, we went to the Boreal forest in northern Ontario, Canada to study the mites and springtails living in a beautiful peatland. We studied mite and springtail communities living in different areas of that peatland for two reasons: first because it is still not well-known what species of mites and springtails are found in peatland communities, and second because we also wanted to know how much they could help decompose leaves. 


\section{WHAT DID WE DO?}

A group of researchers from Western University (London, Ontario, Canada) have been working in a peatland in northern Ontario (Canada) in collaboration with Ontario Provincial government scientists at the Ontario Forest Research Institute. We are trying to answer different questions about peatlands by studying the plants, mites, insects, mercury, carbon, and water at this site. This peatland site is mostly covered in Sphagnum mosses that create raised areas called hummocks (Figure 2B) and depressions called hollows (Figure 2C). Hummocks are an accumulation of mosses and other plants, and they are dry at the surface. On the other hand, hollows, as depressions on the ground, are generally very wet at the surface. For this study, we wanted to know whether mite and springtail communities (secondary decomposers), as well as decomposition rates (how fast dead plants decompose) differed between hummocks and hollows at our peatland site.

\section{What Did We Do in the Peatland?}

One way to study decomposition is to use litterbags [2]. Litterbags are small bags made of a mesh material that can be filled with dead plants; the holes in the mesh allow tiny organisms to come and go. We filled the litterbags (Figure 2D) with leaves of three different plants: moss (Figure 2E), shrub (Figure 2F) (these are small bushes), or sedge leaves (Figure 2G) (these are grass-like plants), and we weighed them to know the initial amount of dry leaves in each litterbag.

In June 2015, we placed one litterbag of each plant type (three litterbags) on five different hummocks (dry raised areas) and in five different hollows (wet depressions). Litterbags were pinned to the soil surface and left there for a whole year so that organisms had enough time to colonize the litterbags and help decompose the leaves. After 1 year, we went back to the peatland site, collected the litterbags, and brought them back to our laboratory at Western University, in southern Ontario (Canada).

\section{What Did We Do in the Laboratory?}

In the laboratory, we placed each litterbag onto a special piece of equipment called a Tullgren funnel (Figure $2 \mathrm{H}$ ) that has a light bulb inside of it, and when it is on, it warms the whole litterbag so that it forces the organisms to move out of the litterbags into a small vial where we can observe them. Afterwards, we cut the litterbags open and dried the leaves in an oven, and then weighed them with a scale. We observed the organisms we collected from the litterbags using a microscope and separated them into different species based on what they looked like. We also counted how many of each species we found in each litterbag. This part of the work took two researchers about 5 days working all day long. Finally, we compared the weight of the plant leaves left at our peatland site for 1 year, to the initial weight of the 
Figure 3

(A) Different levels of decomposition on different leaf types; sedges decomposed more within the 1 year experiment. (B) Hollows had more species and individuals of oribatid mites and springtails. Pictures are not to scale.

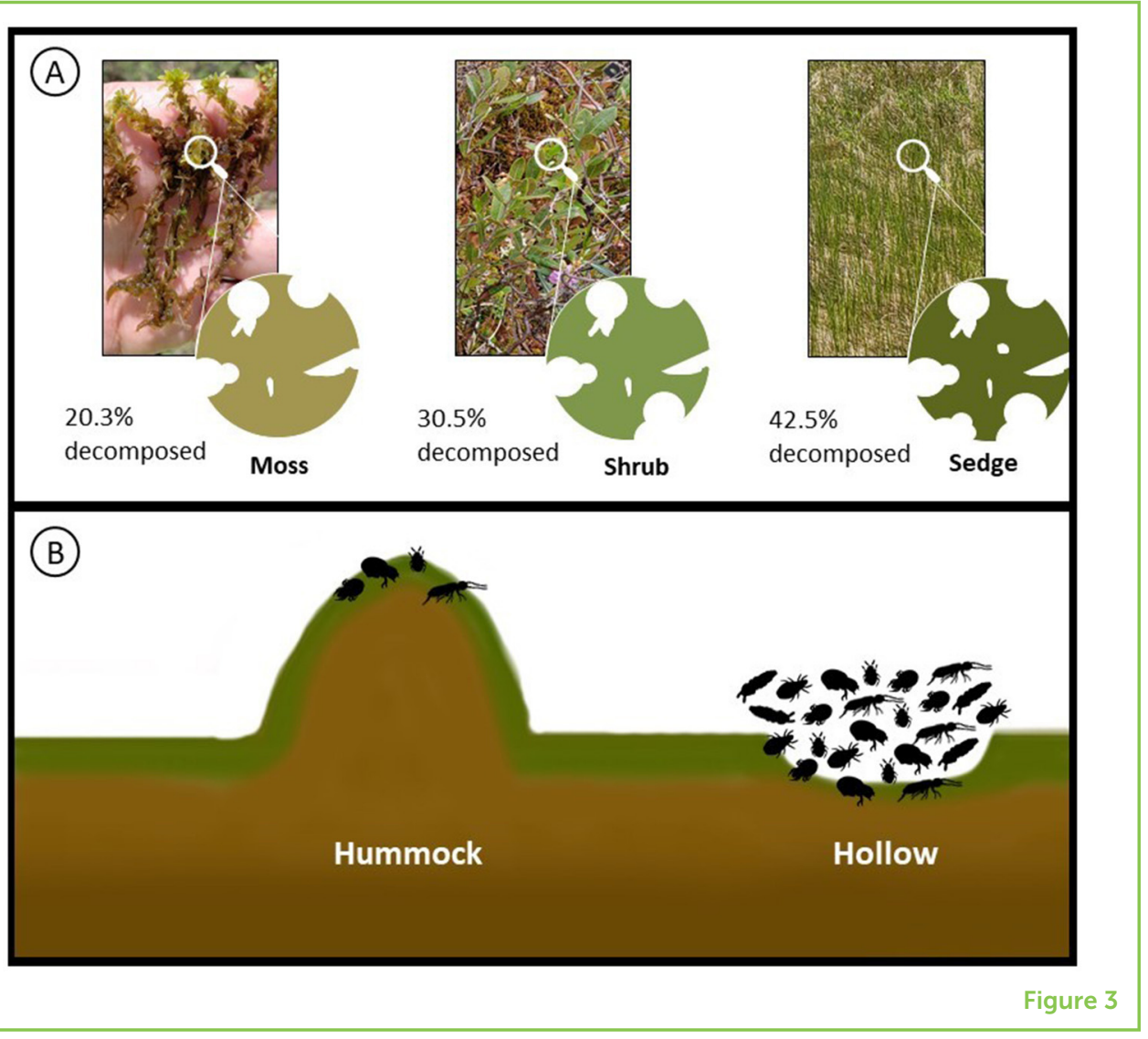

leaves before they went to our peatland site. The difference in weight told us how much of the leaves had decomposed over the course of 1 year, in other words, how much the animals had eaten.

\section{WHAT DID WE FIND?}

Leaves from the different plants decomposed at different rates. The sedge leaves, that resemble grasses (reduction of $42.5 \%$ ), decomposed more than the shrub leaves (reduction of 30.5\%), which in turn decomposed more than the moss (reduction of $20.3 \%$ ) in the litterbags (Figure 3A). However, it did not matter whether the litterbags were on the hummock surface or in the hollow, as we found a similar amount of decomposition in both cases. This was because even though hollows are wetter than hummocks, neither were fully saturated in a way that decomposition would slow significantly in our sites, compared to other submerged parts of the peatland.

A single litterbag had between zero and 203 individual mites and between zero and 123 individual springtails. We found more individual mites and springtails from our litterbags placed in hollows (wet depressions) than on hummocks (dry raised areas) (Figure 3B). But the tiny animals did not have a preferred leaf type, meaning they were found in similar numbers in litterbags that contained sedges, 
shrubs, or mosses. Certain mites called oribatid mites (Figure 1B) were the dominant group in the litterbags $(53.6 \%$ of the total number of individuals) followed by springtails, representing $40 \%$. Other groups of mites that were not numerous, a few spiders, and a few insect larvae, were also collected, but altogether were only $6.4 \%$ of the animals in the litterbags. Besides having more individuals, hollows (wet depressions) also had more species collected. In total, we found 20 species from 506 individual oribatid mites and seven species from 378 individual springtails (Figure 1C). The communities of oribatid mites were more similar to one another in hollows and had the most species present. The species of oribatid mites found in hummocks seemed to be random.

\section{WHY IS THIS IMPORTANT?}

Few studies have been done for mites and springtails in peatlands, so the first reason we did this study was to gain information on what species of oribatid mites lived in our peatland. Also, understanding how the tiny animal communities differ provides us with an idea on how fast or slow decomposition naturally happens on leaves in peatlands.

Although in most cases, oribatid mites and springtails are considered secondary decomposers [3] because they feed on fungi and bacteria, understanding who they are, where they live, and how much they contribute to decomposition processes is important for predicting the amount of carbon released to the atmosphere from soils. Peatland soils are a special case because peatlands only occupy a small portion of the world, but their slow decomposition means peatlands can store very high amounts of carbon [1].

Increases in global temperatures due to climate change are expected to change the plant types we observe in peatlands. Specifically, warmer temperatures will allow sedges to take over where mosses were previously found [4]. In our study, we found that sedges decomposed faster than mosses, and this means that a change in the type of plants in peatlands from mosses to sedges may increase the amount of carbon being released through decomposition.

Even though we did not collect bacteria and fungi in this specific study, other studies by our research group in the same peatland found that communities of fungi [5] and bacteria [6] also varied between hummocks and hollows. Mites and springtails are understudied, so we chose to focus on them. Results for fungi and bacteria also suggest that climate change may change the carbon storage ability of peatlands. In other words, increases in temperature may speed up the overall decomposition of leaves, releasing more carbon dioxide into the atmosphere, and making climate change even more pronounced. Nonetheless, we must engage in the conservation of peatlands, as these are important ecosystems for our life in a future where more 
carbon dioxide will likely be present in the atmosphere. The time for conservation actions is now!

\section{AUTHOR CONTRIBUTIONS}

CB and ZL wrote the manuscript and CB created the figures.

\section{ACKNOWLEDGMENTS}

We were grateful for funding from the Natural Sciences and Engineering Research Council of Canada (NSERC) Discovery Grant program (ZL \#418241-2012) and the Ontario Ministry of Research, Innovation and Science, Early Researcher Award (ZL). We thank Dr. J. McLaughlin (Ontario Ministry of Natural Resources and Forestry) for access to the White River, ON field site and Dr. Brian Branfireun for their continued support with our research program. We thank Dr. Greg Thorn and Dr. Branfireun for some of the pictures. Special thanks to Caitlyn Lyons, who helped us with making the language appropriate for children, and to our great young reviewers and their Science mentors. We also thank Dr. Malte Jochum for the invite to be part of this great initiative.

\section{ORIGINAL SOURCE ARTICLE}

Barreto, C., and Lindo, Z. 2018. Drivers of decomposition and the detrital invertebrate community differ across a hummock-hollow microtopology in Boreal peatlands. Ecoscience 25:39-48. doi: 10.108 0/11956860.2017.1412282

\section{REFERENCES}

1. Gorham, E. 1991. Northern peatlands: role in the carbon cycle and probable responses to climatic warming. Ecol. Appl. 1:182-95.

2. Moore, T. R., Trofymow, J. A., Prescott, C. E., and Titus, B. D. 2017. Can short-term litter-bag measurements predict long-term decomposition in northern forests? Plant Soil 416:419-26. doi: 10.1007/s11104-017-3228-7

3. Lehmitz, R., and Maraun, M. 2016. Small-scale spatial heterogeneity of stable isotopes signatures $\left(\delta^{15} \mathrm{~N}, \delta^{13} \mathrm{C}\right)$ in Sphagnum sp. transfers to all trophic levels in oribatid mites. Soil Biol. Biochem. 100:242-51. doi: 10.1016/j.soilbio.2016.06.005

4. Dieleman, C. M., Branfireun, B. A., Mclaughlin, J. W., and Lindo, Z. 2015. Climate change drives a shift in peatland ecosystem plant community: implications for ecosystem function and stability. Glob. Change Biol. 21:388-95. doi: $10.1111 /$ gcb.12643 
5. Asemaninejad, A., Thorn, R. G., and Lindo, Z. 2017. Vertical distribution of fungi in hollows and hummocks of boreal peatlands. Fungal Ecol. 27:59-68. doi: 10.1016/j.funeco.2017.02.002

6. Asemaninejad, A., Thorn, R. G., Branfireun, B. A., and Lindo, Z. 2019. Vertical stratification of peatland microbial communities follows a gradient of functional types across hummock-hollow microtopographies. Ecoscience 26:249-58. doi: 10.1080/11956860.2019.1595932

SUBMITTED: 19 January 2020; ACCEPTED: 13 July 2020;

PUBLISHED ONLINE: 21 August 2020.

EDITED BY: Malte Jochum, German Centre for Integrative Biodiversity Research (iDiv), Germany

CITATION: Barreto C and Lindo Z (2020) Decomposition in Peatlands: Who Are the Players and What Affects Them? Front. Young Minds 8:107. doi: 10.3389/frym.2020. 00107

CONFLICT OF INTEREST: The authors declare that the research was conducted in the absence of any commercial or financial relationships that could be construed as a potential conflict of interest.

COPYRIGHT @ 2020 Barreto and Lindo. This is an open-access article distributed under the terms of the Creative Commons Attribution License (CC BY). The use, distribution or reproduction in other forums is permitted, provided the original author(s) and the copyright owner(s) are credited and that the original publication in this journal is cited, in accordance with accepted academic practice. No use, distribution or reproduction is permitted which does not comply with these terms.

\section{YOUNG REVIEWERS}

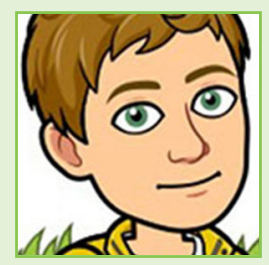

\section{ADAM, AGE: 14}

$\mathrm{Hi}$, my name is Adam. I live with my parents, older brother, dog, fish, and two birds. I am a big fan of Science and History. I like to draw, write, and read. My favorite sport is soccer (or football). I enjoy swimming in the ocean and playing video games.

\section{ALEXANDER, AGE: 12}

I am a 12 years old boy in the seventh grade and my favorite subject is mathematics. I like to play the guitar and am learning how to play drums.

\section{AUTHORS}

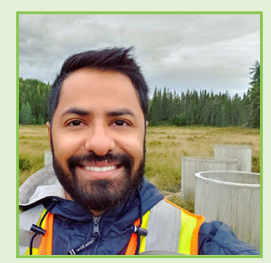

\section{CARLOS BARRETO}

Since a very young age I realized that I liked animals, maybe too much. Science in school was always my favorite discipline, all the way through to high school. It is then that I decided that I wanted to do something that involved science and animals. I tried to be a vet; it did not work out. No regrets. So, I became an Ecologist a few years later, 


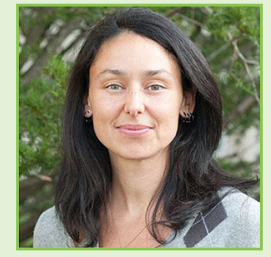

and since then, I have worked with little animals (mostly insects and mites) in tropical forests, iron ore and limestone caves, boreal forests, urban fields, and peatlands on three continents; South America, North America, and Europe. ${ }^{*}$ cbarreto@uwo.ca torcid.org/0000-0003-2859-021X

\section{ZOË LINDO}

Dr. Zoë Lindo is an expert on soil biodiversity and ecosystem function. She has worked extensively in Canadian forests including the mixed-wood boreal of Alberta, the subarctic taiga of Quebec, the coastal temperate rainforest of British Columbia, and the black spruce/peatlands of Ontario. "The overall focus of my research aims to mitigate biodiversity loss in association with human-induced environmental change and maintain ecosystem functioning in Canadian forest and soil ecosystems. I describe myself as a biodiversity scientist to encompass the breadth of my research in the areas of community ecology, soil ecology, and taxonomy." " orcid.org/0000-0001-9942-7204 